\title{
THE EFFECT OF TIME IN A MULTI-DIMENSIONAL MARRIAGE MARKET MODEL
}

\author{
Mário Vozár
}
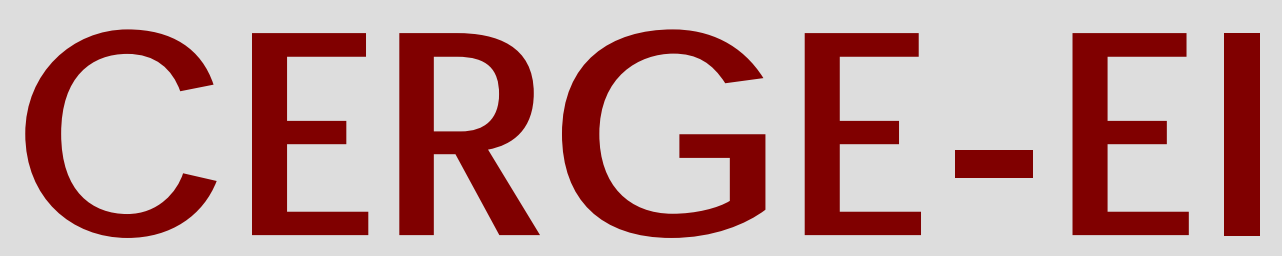

Charles University Centerfor Economic Research and Graduate Education Academy of Sciences of the Czech Republic Ec onomic s Institute 


\title{
Working Paper Series (ISSN 1211-3298)
}

\section{The Effect of Time in a Multi-Dimensional Marriage Market Model}

\author{
Mário Vozár
}

CERGE-EI

Prague, September 2010
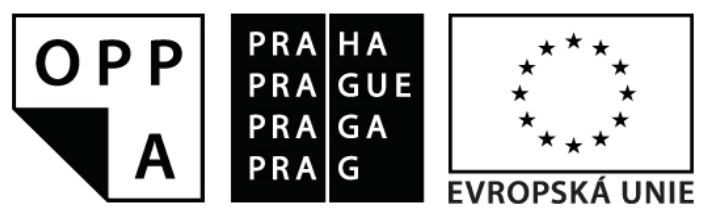

EVROPSKÝ SOCIÁLNÍ FOND

PRAHA \& EU: INVESTUJEME DO VAŠÍ BUDOUCNOSTI

Projekt je financován Evropským sociálním fondem, rozpočtem hl. města Prahy a státním rozpočtem 
ISBN 978-80-7343-215-7 (Univerzita Karlova. Centrum pro ekonomický výzkum a doktorské studium)

ISBN 978-80-7344-205-7 (Národohospodářský ústav AV ČR, v.v.i.) 


\title{
The Effect of Time in a Multi-Dimensional Marriage Market Model*
}

\author{
Mário Vozár ${ }^{\dagger}$ \\ CERGE-EI ${ }^{\ddagger}$
}

September 2010

\begin{abstract}
In the paper, I develop a theoretical model of a marriage market that accounts for the effect of aging on agents' wealth and physical attractiveness. Furthermore, I use the model to analyze how the structure and more importantly the stability of the marriage market is affected by the increased female income prospects. First, I find that the changes in agents' characteristics can result in an incentive to re-match and thus provide yet another explanation of the phenomenon of divorce. Second, comparative statics show that an increase in female income prospects increases the divorce rate, which suggests that the stabilization effect of being more attractive for a current partner is dominated by the effect of increased female marriage market opportunities.
\end{abstract}

\begin{abstract}
Abstrakt
Ve své práci představuji teoretický model formování partnerských vztahů schopný popsat dopad změn charakteristik obou partnerů. Dále vyvinutý model využívám k analýze rostoucí účasti žen na trhu práce, spojené s následným růstem jejich očekávaného př́ijmu, což má důležitý dopad jak na vlastnosti obou partnerů, tak na jejich životní rozhodnutí. Výstupy z představeného modelu ukazují, že změny vlastností obou partnerů mohou mít za následek rozpad vztahu, a model tak poskytuje vzhledem $\mathrm{k}$ dosavadní teorii dodatečné vysvětlení. Zároveň komparativní analýza ukazuje, že růst očekávaného příjmu u žen způsobuje růst pravděpodobnosti rozvodu, což je v souladu s empirickou literaturou.
\end{abstract}

Keywords: Aging, Divorce, Two-Sided Matching, Gale-Shapley marriage problem JEL classification: J12, J14, J16

*I would like to express my gratitude to Peter Katuščák for invaluable comments, suggestions and guidance. I am also thankful to Byeongju Jeong and Fabio Michelucci for comments on earlier drafts. All errors remaining in this text are the responsibility of the author.

$\dagger$ Email: mario.vozar@cerge-ei.cz

${ }^{\ddagger}$ Center for Economic Research and Graduate Education--Economics Institute, a joint workplace of Charles University in Prague and the Academy of Sciences of the Czech Republic. Address: CERGE-EI, P.O. Box 882, Politických vězňů 7, Prague 1, 111 21, Czech Republic

The work was supported by the grant SVV-2010-261 801. 


\section{Introduction}

The significant impact the marriage market has on population growth, the labor supply of women, and the inequality of income has been of great interest to economists. Various theoretical models have been constructed, which attempt to describe matching behavior and equilibrium matching outcomes. Most of these models (with exception of Masters, 2008) assume that the agents' characteristics do not change over time, and thus, the results depend on this assumption. However, in the real world when choosing an optimal partner for marriage, people base their decision on several important characteristics or attributes, tangible as well as intangible, which clearly succumb to the effect of time.

In addition to the natural aging of agents over time, significant changes over the last forty years, in the female labor force participation followed by an increase in female income, have had an impact on agents' characteristics as well as on their marital decisions. Therefore, existing models of the marriage market, restricted by the property of time-stationary types, neglect important effects that these ongoing changes have on the agents' matching behavior and the equilibrium in matching outcomes.

I develop a theoretical matching framework that accounts for the effect of time on agents' characteristics. In particular, I construct a model, where men and women differ in two characteristics, wealth and physical attractiveness, with the effect of time to account for their appreciation and depreciation respectively. The choice of these characteristics is motivated by Becker (1973) who considered agents' characteristics such as human and physical capital to be important factors in determining the matching pattern and the allocation of marital surplus. The need for a dynamic framework incorporating the effect of time is clear since these factors indeed change over time, either in a positive or a negative way. Therefore, equilibrium matching, as well as an incentive to re-match, would be consequently exposed to the effect of time as well.

This model suggests yet another explanation of the existence of divorce. Ac- 
cording to the existing theoretical literature, re-matching occurs due to one of the following reasons: a continuous search for a better partner in the presence of search frictions and the delayed realization of a low match quality. My approach proposes an alternative explanation. I argue, that even though at the time of marriage the match has been stable and there are assumed to be no frictions, the stability may be broken as partners age over time. As the result of aging, agents' preferences over their potential partners (as well as preferences of potential partners over them) may change and thus break the stability of the match.

This novel approach of incorporating the effect of time into the multidimensional matching environment allows me to theoretically investigate the impact of changes, such as increased female labor force participation, have had on the marriage market. I find, that the increase in female income prospects increases the measure of divorces. This suggests that increased female attractiveness on the marriage market has more a pronounced match de-stabilization effect due to the increased female opportunities to find a better partner, as compared to the stabilization effect of increased attractiveness for the current partner.

\section{Literature Review}

The model possesses two main features, multi-dimensionality in agents' characteristics and the effect of time. The literature review concentrates on each of these aspects separately. I employ the non-transferable utility approach mainly for two reasons. First and most important, this study concentrates on the changes in agents characteristics which may play a significant role when deciding for the matching partner. I assume that the agent's utility from the match depends on the partner's type as well as the agent's own type, which is determined by his/her characteristics. Moreover, as Rasul (2006) argues, empirical evidence suggests that households do not reach efficient bargaining, and thus, it is more reasonable to assume utility is non-transferable between partners. 
The multidimensional approach I employ contains several differences to the main stream of the theoretical marriage market literature. In particular, the works of Bergstrom \& Bagnoli (1993); Burdett \& Coles (1997); Cornelius (2003); and Smith (2006) assume that agents differ only in one characteristic, which can be seen as their quality. This assumption directly implies the existence of a positive assortative matching in the equilibrium. It means that the agent with the highest quality is matched with a partner from the opposite gender with the highest quality, the agent with the second highest quality is matched with a partner from the opposite gender with the second highest quality etc. The property of positive assortativeness does not necessary hold when one accounts for the possibility that agents differ in multiple characteristics. As Mailath and Postlewaite (2004) show, the latter setup may result in different agents having different rankings over potential partners, which may break the perfectly positive assortative matching observed under the previous set-up. While Mailath and Postlewaite assume that agents still value only one partner's characteristic, and the other one has no direct impact on an agents' utility, Bjerk (2009) already assumes a multidimensional approach where agents' utility depends on both partner's characteristics. Beside this fact, in the set-up with the effect of aging, it is natural to assume agents being heterogeneous in more than one characteristic. In the real world, while aging, there are certain characteristics which appreciate over time and some that depreciate over time. A multi-dimensional framework, thus, allows me to take into account this fact rather than assume that there is only one agent's characteristic seen as the match quality for the spouse, as for example, in Burdett \& Coles (1997).

However, as mentioned before, neither of the above studies account for the effect of aging on the agents' characteristics. Although the effect of time itself has already been introduced into the marriage market literature by Bergstrom \& Bagnoli (1993), aging only plays a role in revealing male quality and does not change the agent's characteristics over time. The first one to account for the effect of aging itself is Masters (2008) but the fact that agents differ only in one attribute results 
in an unrealistic identical probability of divorce over the lifetime for all agents. As opposed to Masters (2008), my proposed multidimensional approach combining aging with exante heterogeneous agents allows me to evaluate an agent's own marital decisions with respect to his or her own unique attributes.

\section{The Model}

To model the marriage market outcome with exante heterogeneous agents and stochastic aging present, I employ the two-period, "overlapping generations" structure (OLG). At the beginning of each period, matching takes place, and the equilibrium is obtained by the standard Gale-Shapley matching framework.

Gale \& Shapley (1962) developed a two-sided matching algorithm with several desirable properties. First, equilibrium matching is stable, such that there is no man and woman that would both prefer being matched with each other rather than with their current partners. Even though there is the possibility that the set of stable allocations (core) contains multiple equilibria, the authors show that under truthful revelation of preferences, the equilibrium outcome is the best stable allocation for those that propose and the worst stable allocation for those whose actions are to accept or to reject the proposal. This implies that even though the equilibrium in general is not unique, one always knows which type of equilibrium was obtained with respect to the agents' welfare. Moreover, Eeckhout (2000) and Clark (2006) provide conditions for preferences that are sufficient for the uniqueness of the Gale-Shapley matching outcome, which is useful for meaningful comparative statics.

Even though one can argue that the search-based approach with frictions is a more realistic set-up, the development of new search technologies like on-line dating diminishes the constraints on meeting opportunities and at the same time decreases costs of search. Thus, as the search costs are decreasing, the outcome of search models becomes in the limit consistent with the Gale-Shapley algorithm outcome as has been formally shown by Adachi (2003). Moreover, the Gale-Shapley approach when 
compared to the search-based model can be characterized by analytical simplicity with respect to obtaining an equilibrium, proving its existence and in my set-up most importantly, uniqueness necessary for meaningful comparative statics.

The Gale-Shapley deferred acceptance algorithm consists of several rounds in which yet unpaired agents of an exante chosen group make their matching proposals. For now ${ }^{1}$, I shall follow social norm as well as prevailing evidence from the on-line dating sites (Hitsch, Hortasu \& Ariely, 2010) and assume that males make proposals and females either accept or reject them based on their preference profiles. The preference structure of the men can be described by the ordering matrix of men $\Omega_{M}$ and similarly for women $\Omega_{W}$, where every man and every woman prefer to be married to remaining single.

The algorithm is as follows. In round $i$, every unmatched man makes a proposal to the highest ranked woman he has not proposed to yet based on his own ordering structure within $\Omega_{M}$. Then, every woman who obtained a proposal and is yet unmatched tentatively accepts it since marriage is preferred to being single. In this case, the woman obtaining a proposal is already tentatively matched; she accepts or rejects the proposal based on her own ordering structure within $\Omega_{W}$. In the case of acceptance, the woman's former partner becomes unmatched and again makes a proposal in the next round to his highest ranked woman he has not proposed to yet. This procedure continues until every man and woman are matched.

First, I will present the benchmark version of the model without gender asymmetry. The aim of the benchmark model is to demonstrate the ability of the model with the effect of aging to explain the phenomenon of divorce.

\subsection{Set-up}

The simple model I present below illustrates a matching structure and a potential for divorce in a multidimensional setting with the effect of time in the form of stochastic aging. To keep things tractable, the basic set-up with respect to the

\footnotetext{
${ }^{1}$ I shall show that given the preferences of agents, the matching outcome is unique and thus does not depend on the choice of the proposing group.
} 
agents' characteristics follows Bjerk (2009) with agents exante heterogeneous in wealth $w$ and beauty $b$, where both can be either of a high or low level, and these are independently realized at the moment the agent enters the market and observable by other agents on the market.

The agent is born as a high wealth $(\bar{w})$ individual with the probability $x<1 / 2$ and as a high beauty $(\bar{b})$ individual with the probability $z<1 / 2$. Moreover, I assume that $x<z$, which reflects the distribution of these two attributes in the society, since wealth distribution is considered to possess heavier right tail than distribution of the Body Mass Index, which can be considered to be a proxy for beauty. Thus, each agent is characterized by his or her combination of characteristics $(w, b)$, and the distribution of types within gender at the time of entering the marriage market can be described with the following probabilities: $(\bar{w}, \bar{b})$ with probability $\pi_{1}=x z$; $(\bar{w}, \underline{b})$ with probability $\pi_{2}=x(1-z) ;(\underline{w}, \bar{b})$ with probability $\pi_{3}=(1-x) z$; and finally, $(\underline{w}, \underline{b})$ with probability $\pi_{4}=(1-x)(1-z)$. The initial assumption on $x$ and $z$ thus implies $\pi_{1}<\pi_{2}<\pi_{3}<\pi_{4}$.

To employ the effect of time, I introduce the OLG structure with two generations, young and old. Old agents are marked with subscript or superscript $o$, while young agents are recognized by subscript or superscript $y$. Agents in the cohort of the old, possess again a high or a low level of wealth $w$ and beauty $b$ with the following transition probabilities conditional on their levels when young: $\operatorname{Prob}\left(\bar{w}_{o} \mid \bar{w}_{y}\right)=1$; $\operatorname{Prob}\left(\underline{b}_{o} \mid \underline{b}_{y}\right)=1 ; \operatorname{Prob}\left(\bar{w}_{o} \mid \underline{w}_{y}\right)=p<1 / 2 ;$ and $\operatorname{Prob}\left(\bar{b}_{o} \mid \bar{b}_{y}\right)=q<1 / 2$.

Thus, in this simple example I consider to be a benchmark case, I assume there is no gender asymmetry with respect to the aging patterns as well as to the distribution of their types. The Markov matrix of the type transition for the old agents is summarized in Table 1.

In order to obtain equilibrium matching, I rely on the Gale-Shapley matching algorithm described in the previous section. However, there is a need to assign preferences over the potential spouses to each individual. In addition, due to the 


\begin{tabular}{ccccccc} 
Density & & & $(\bar{w}, \bar{b})_{o}$ & $(\bar{w}, \underline{b})_{o}$ & $(\underline{w}, \bar{b})_{o}$ & $(\underline{w}, \underline{b})_{o}$ \\
\cline { 1 - 1 }$\pi_{1}$ & & $(\bar{w}, \bar{b})_{y}$ & $q$ & $1-q$ & & \\
$\pi_{2}$ & & $(\bar{w}, \underline{b})_{y}$ & & 1 & & \\
$\pi_{3}$ & & $(\underline{w}, \bar{b})_{y}$ & $p q$ & $p(1-q)$ & $(1-p) q$ & $(1-p)(1-q)$ \\
$\pi_{4}$ & & $(\underline{w}, \underline{b})_{y}$ & & $p$ & & $1-p$ \\
\hline
\end{tabular}

Table 1: Markov matrix of type transition

OLG structure of the model, agents inter-temporal behavior has to be specified. In this context, I assume zero divorce costs even though due to the discrete structure of the model the results would be robust to small but positive divorce costs. There are several reasons behind this assumption. Most importantly, in the case where divorce costs are not present, there is no difference between agents behaving in a myopic and forward-looking way. This is because there is no punishment for leaving the match or for being left; the agent does not have to care about what his/her actions today imply for his or her future. Since matching takes place at the beginning of each period, agents care only about the current period matching, and thus, optimal behavior is the myopic one. Moreover, the introduction of divorce costs would require an introduction of some form of utility function and connection of the divorce costs to this utility form. However, introducing of the utility function would add another layer of complexity, which is not yet desirable for this simple demonstrative exercise.

Following Bjerk (2009), I assume a truthful revelation of preferences conditional on the individual's level of wealth he or she possesses. Moreover, as I argued in the previous paragraph, in the presence of zero divorce costs, the agent cares only about the current period match, and thus, every agent possesses the following preferences conditional on his/her own wealth level:

$$
\begin{aligned}
& \text { for } \bar{w} \mid(\bar{w}, \bar{b})>(\underline{w}, \bar{b})>(\bar{w}, \underline{b})>(\underline{w}, \underline{b}) \\
& \text { for } \underline{w} \mid(\bar{w}, \bar{b})>(\bar{w}, \underline{b})>(\underline{w}, \bar{b})>(\underline{w}, \underline{b}) .
\end{aligned}
$$

To provide an intuition for the proposed preference structure, I follow the rea- 
soning of Bjerk (2009). As the author states, it is reasonable to assume that after the agents match, they enjoy the utility from the total houshold wealth which is seen as the public good. On the other hand, the partner's beauty is seen as a private good and benefits only the spouse. Further, the assumption of diminishing marginal utility from the household wealth implies that the marginal rate of substitution between a partner's beauty and a partner's wealth increases as one's own wealth level increases. In my case, as can be seen in the preference structure (1) and (2), a high wealth individual thus prefers a partner with high beauty rather than with a high wealth level.

In addition, the given preference structure ensures that the equilibrium matching is unique, which is formally stated and proved by the following proposition.

Proposition 1: Given the preference ordering described by (1) and (2), there is a unique stable matching given by the Gale-Shapley algorithm for any given distribution of agents' characteristics.

\section{Proof: In Appendix}

Even though, the equilibrium matching is unique given the distribution of agents' types and given the aging patterns, on the micro level ties the agents exhibit exist between potential partners with the same characteristics. Without any additional assumption, these ties would be resolved by chance. However, one can argue that in real life agents choose their partner not just with respect to a partner's characteristics, but with respect to a partner's age as well. Therefore, I impose a condition where each agent prefers a partner of the same age as herself if there are two potential partners of different ages but otherwise, equal in wealth and beauty. Therefore, the preference structure described by equations (1) and (2) can be re-written to the following system of preferences.

for $\bar{w}_{y} \mid(\bar{w}, \bar{b})_{y}>(\bar{w}, \bar{b})_{o}>(\underline{w}, \bar{b})_{y}>(\underline{w}, \bar{b})_{o}>(\bar{w}, \underline{b})_{y}>(\bar{w}, \underline{b})_{o}>(\underline{w}, \underline{b})_{y}>(\underline{w}, \underline{b})_{o}$ 


$$
\begin{aligned}
& \text { for } \bar{w}_{o} \mid(\bar{w}, \bar{b})_{o}>(\bar{w}, \bar{b})_{y}>(\underline{w}, \bar{b})_{o}>(\underline{w}, \bar{b})_{y}>(\bar{w}, \underline{b})_{o}>(\bar{w}, \underline{b})_{y}>(\underline{w}, \underline{b})_{o}>(\underline{w}, \underline{b})_{y} \\
& \text { for } \underline{w}_{y} \mid(\bar{w}, \bar{b})_{y}>(\bar{w}, \bar{b})_{o}>(\bar{w}, \underline{b})_{y}>(\bar{w}, \underline{b})_{o}>(\underline{w}, \bar{b})_{y}>(\underline{w}, \bar{b})_{o}>(\underline{w}, \underline{b})_{y}>(\underline{w}, \underline{b})_{o} ;
\end{aligned}
$$

and

$$
\text { for } \underline{w}_{o} \mid(\bar{w}, \bar{b})_{o}>(\bar{w}, \bar{b})_{y}>(\bar{w}, \underline{b})_{o}>(\bar{w}, \underline{b})_{y}>(\underline{w}, \bar{b})_{o}>(\underline{w}, \bar{b})_{y}>(\underline{w}, \underline{b})_{o}>(\underline{w}, \underline{b})_{y} \text {. }
$$

Moreover, it is natural to assume that an agent indifferent between staying with a current partner and remarrying, chooses to stay in the current relationship, which can be seen as the limit case of the divorce cost approaching zero. Both of these conditions allow me to observe the stability of the matching as well as the re-matching patterns. Furthermore, the addition of this lexicographic element of the preferences does not influence the uniqueness of the stable matching, and the proof would just be an extension of the proof of Proposition 1.

Given the distribution of agents' types, the agents' inter-temporal behavior, and their preference ordering over the potential spouses, I can finally employ the GaleShapley deferred acceptance algorithm to obtain stable matches. Since I use GaleShapley within the two-period framework, it is important to note that this achieved stability means that there is no man and woman currently not matched together who would prefer to be matched together in the current period. It is important to see that this within period stability does not ensure inter-temporal stability since as agents age, their characteristics change and thus agents' preferences over potential partners are subject to change as well. As a consequence, aging may lead to a potential re-matching in the second period. Since at this stage I assume that the distribution as well as the size of the newborns' cohort do not change over time, the equilibria in each period coincide.

As I already mentioned above, the equilibrium matching is unique conditional on the distribution of agents' types and given the aging patterns. In particular, it is 
reasonable to expect that two societies, sufficiently different from each other, may exhibit different equilibrium matching. This is indeed the case in this benchmark model, where two equilibria exist conditional on the choice of model parameters $(x, y, p, q)$. These two equilibria, denoted as Case 1 and Case 2, are formalized in Lemma 1 and Lemma 2 respectively.

Lemma 1: The equilibrium matching is unique and has the structure described by Table 2 under the condition $\pi_{1}(1-q)+\pi_{2}+\pi_{3} p(1-q)+\pi_{4} p-\pi_{3}(1-p) q>$ $\pi_{3}-\pi_{2}$ (Case 1).

Proof: In Appendix

Lemma 2: The equilibrium matching is unique and has the structure described by Table 3 under the condition $\pi_{1}(1-q)+\pi_{2}+\pi_{3} p(1-q)+\pi_{4} p-\pi_{3}(1-p) q<$ $\pi_{3}-\pi_{2}$ (Case 2).

\section{Proof: In Appendix}

Both Table 2 and Table 3 show that even though inter-generational marriages can be observed, the majority of matches are observed between agents of the same age. Moreover, agents with both characteristics being of the high or low level are matched together and thus positive assortative matching applies for them. On the contrary, agents with mixed levels of characteristics exhibit negative assortative matching. These observations are expected and are given by the structure of the preference ordering. However, interesting findings, which are not directly observable from Table 2 and Table 3, are linked to the stability of marriages, the overall measure of match separations and its distribution across the groups. In the next paragraph, I shall provide the analysis of match stability for each of the presented equilibria. 


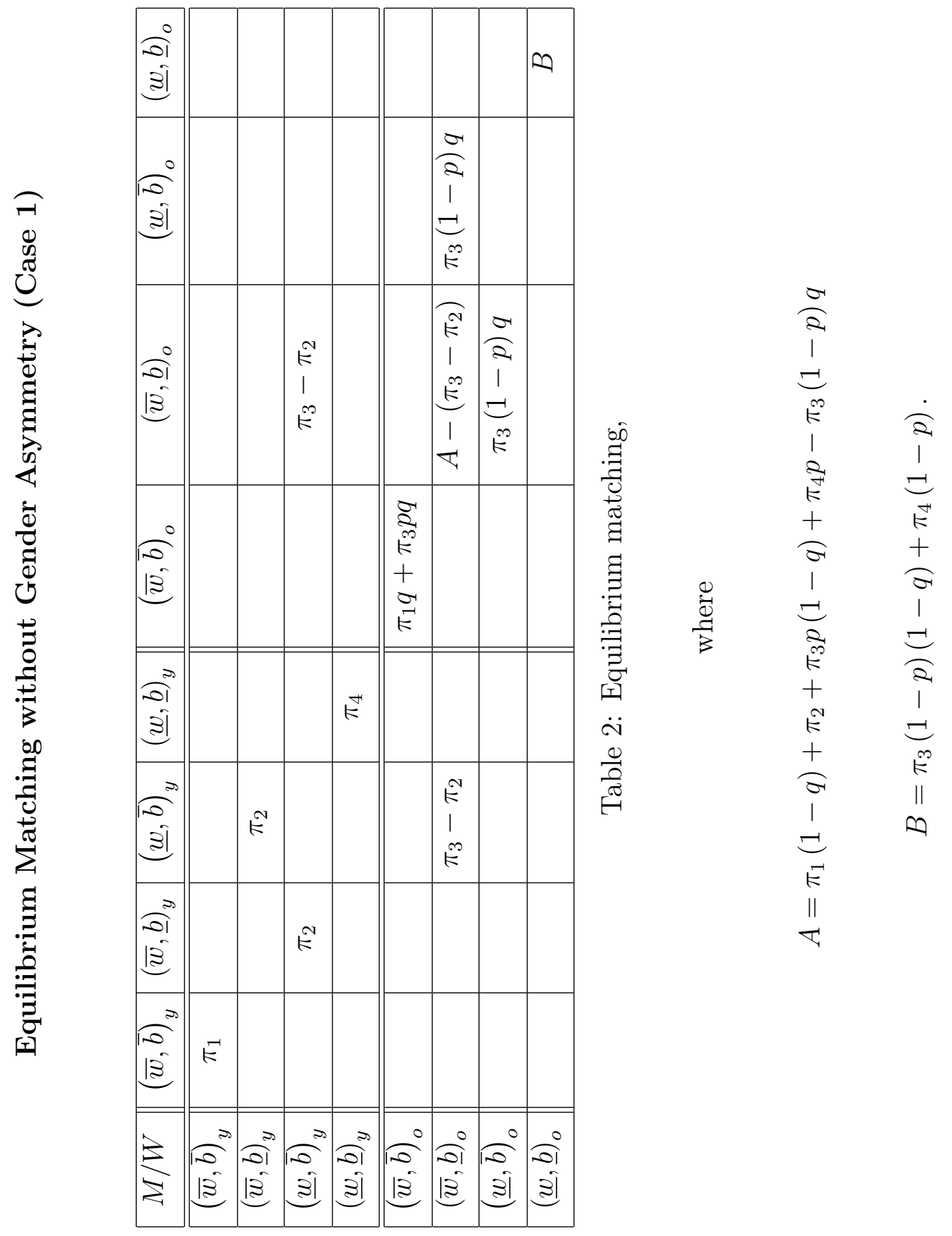




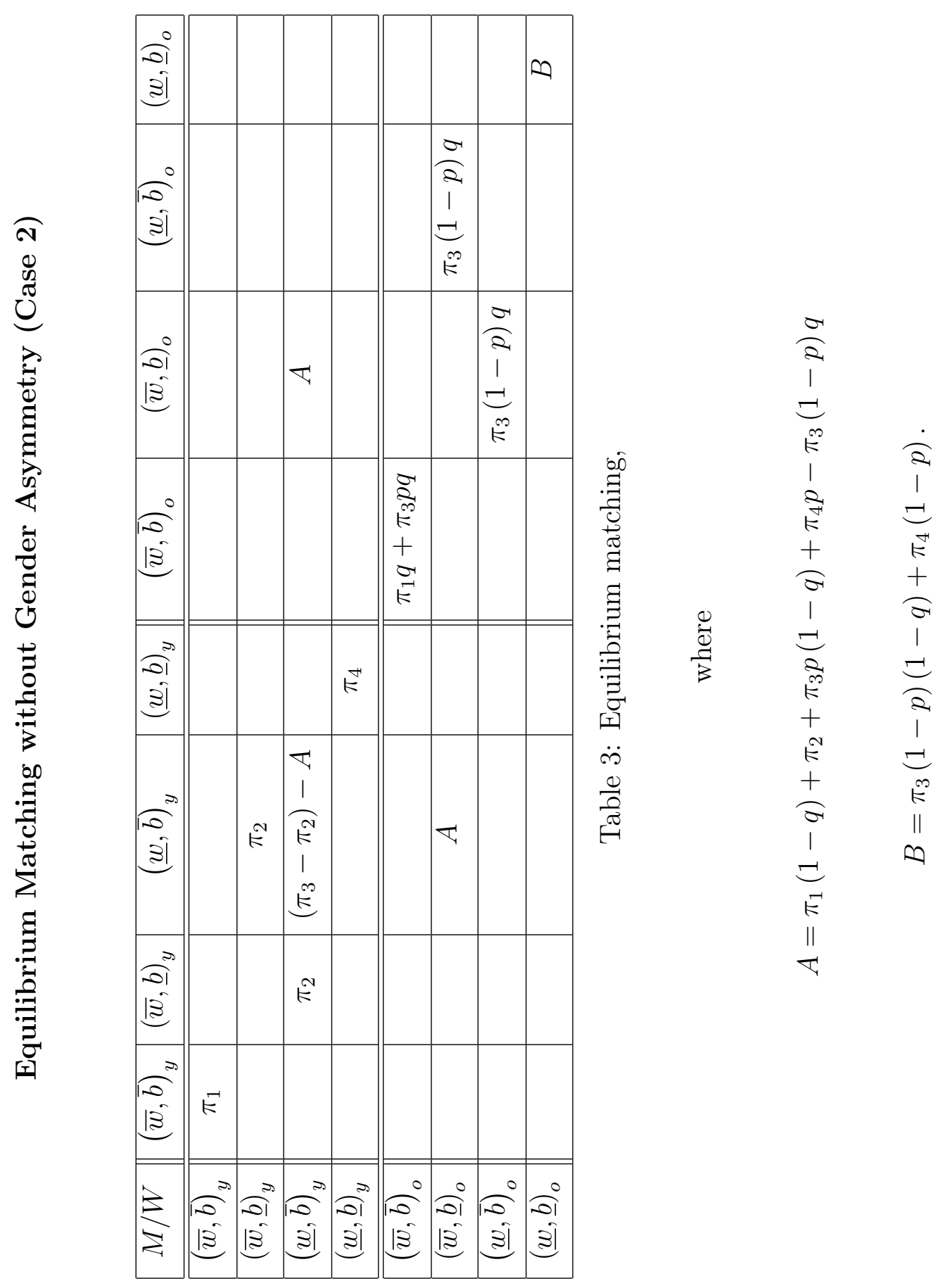


To determine the probability of match separation in equilibrium denoted as Case 1, one has to analyze the stability for each of the four types of matches between the young agents pictured in the second quadrant of Table 2. For the equilibrium denoted as Case 2, one has to analyze the stability for each of the five type of matches between the young agents pictured in the second quadrant of Table 3 . To illustrate this analysis, I will discuss the stability of the match between men $(\bar{w}, \bar{b})_{y}$ and women of the same type in Case 1 equilibrium, which is summarized in Table 4.

\begin{tabular}{c|c|c|c}
\multicolumn{4}{c}{ Potential matches of $(\bar{w}, \bar{b})_{y}$ with $(\bar{w}, \bar{b})_{y}$ (when old) } \\
\hline Men & Women & prob. of occurrence & remain together \\
\hline$(\bar{w}, \bar{b})_{o}$ & $(\bar{w}, \bar{b})_{o}$ & $q^{2}$ & Yes \\
$(\bar{w}, \bar{b})_{o}$ & $(\bar{w}, \underline{b})_{o}$ & $q(1-q)$ & No \\
$(\bar{w}, \underline{b})_{o}$ & $(\bar{w}, \bar{b})_{o}$ & $(1-q) q$ & No \\
$(\bar{w}, \underline{b})_{o}$ & $(\bar{w}, \underline{b})_{o}$ & $(1-q)^{2}$ & Yes \\
\hline
\end{tabular}

Table 4: Transition to old cohort matches and their stability

First, it is important to realize that even though both agents possess the same levels of wealth and beauty, in the second period each partner may transition into the $(\bar{w}, \bar{b})_{o}$ or $(\bar{w}, \underline{b})_{o}$ state. Thus, in the second period, four possible match realizations may occur with probabilities conditional on the given aging patterns. However, the fourth quadrant of Table 2 shows that match realizations between type $(\bar{w}, \bar{b})_{o}$ and type $(\bar{w}, \underline{b})_{o}$ are not possible, and thus, the probability of match separation for the match between male $(\bar{w}, \bar{b})_{y}$ and female of the same type is $2 q(1-q)$.

The complete type specific measures of divorces for Case 1 equilibrium can be found in Table 5 and for Case 2 equilibrium in Table 6.

Stability of matches ( measures )

\begin{tabular}{c|c|c|c}
\hline Men & Women & \# of matches & prob. of divorce \\
\hline$(\bar{w}, \bar{b})_{y}$ & $(\bar{w}, \bar{b})_{y}$ & $\pi_{1}$ & $2 q(1-q)$ \\
$(\bar{w}, \underline{b})_{y}$ & $(\underline{w}, \bar{b})_{y}$ & $\pi_{2}$ & $p q+(1-p)(1-q)$ \\
$(\underline{w}, \bar{b})_{y}$ & $(\bar{w}, \underline{b})_{y}$ & $\pi_{2}$ & $p q+(1-p)(1-q)$ \\
$(\underline{w}, \underline{b})_{y}$ & $(\underline{w}, \underline{b})_{y}$ & $\pi_{4}$ & $2 p(1-p)$ \\
\hline
\end{tabular}

Table 5: Match separation measures (Case 1) 
Stability of matches ( measures )

\begin{tabular}{c|c|c|c}
\hline Men & Women & \# of matches & prob. of divorce \\
\hline$(\bar{w}, \bar{b})_{y}$ & $(\bar{w}, \bar{b})_{y}$ & $\pi_{1}$ & $1-q^{2}$ \\
$(\bar{w}, \underline{b})_{y}$ & $(\underline{w}, \bar{b})_{y}$ & $\pi_{2}$ & $1-(1-p) q$ \\
$(\underline{w}, \bar{b})_{y}$ & $(\bar{w}, \underline{b})_{y}$ & $\pi_{2}$ & $1-(1-p) q$ \\
$(\underline{w}, \bar{b})_{y}$ & $(\underline{w}, \bar{b})_{y}$ & $\left(\pi_{3}-\pi_{2}\right)-A$ & $1-p^{2} q^{2}-2 p q(1-p)(1-q)-(1-p)^{2}(1-q)^{2}$ \\
$(\underline{w}, \underline{b})_{y}$ & $(\underline{w}, \underline{b})_{y}$ & $\pi_{4}$ & $1-(1-p)^{2}$ \\
\hline
\end{tabular}

Table 6: Match separation measures (Case 2)

Thus, to sum up, both equilibria in the benchmark model with no gender asymmetry show that the effect of aging can result in the incentive to re-match even though there are no frictions, and the quality of the match is observable. Thus aging, modeled via the changes in the agents' characteristics, provides yet another explanation of the phenomenon of divorce and thus complements the existing theories of divorce. Moreover, I found that the probability of match separation is conditional on the type of the agent as well as on the type of the partner. In other words, the match separation is more likely to occur if partners age along different trajectories. This suggests, that changes in gender asymmetry in the aging growth paths can play a significant role in divorce rate changes.

Therefore, in the following sub-section, I shall concentrate on the comparative statics with respect to differences between the genders' wealth growth prospects, which I believe reflect labor market asymmetry between males and females. I shall discuss how the presence as well as changes in gender asymmetry with respect to growth of wealth influences the stability of the equilibrium matching.

\subsection{Comparative statics with respect to gender aging asym- metry}

The goal of this section is to analyze how the increasing female income prospects influence the equilibrium matching. Over the last 40 years, we observe the continuous closing of the wage gap between males and females. In addition to the increases of the female labor force participation over the years, female income prospects 
have improved. Various empirical studies (Bremmer \& Kesselring, 2004; Kalmijn \& Poortman, 2006; Teachman, 2010) suggest that an increase in a wife's earnings increases the probability of divorce.

In the benchmark case of the model presented above, the gender asymmetry is not present. In this section, I concentrate on the case in which I assume a lower female labor force participation and thus smaller changes in female wealth status over time.

The distribution of the agents' characteristics as well as aging patterns for males' wealth and beauty remain unchanged in the model with gender asymmetry present. Therefore, the transition of young males to the second period is described by Table 1 . However, the aging pattern of females' wealth changes assume that $\operatorname{Prob}\left(\bar{w}_{o} \mid \underline{w}_{y}\right)=$ $r<p$. The Markov matrix of the young females' transition to the second period is described by Table 7 .

\begin{tabular}{ccc|cccc} 
Density & & & $(\bar{w}, \bar{b})_{0}$ & $(\bar{w}, \underline{b})_{o}$ & $(\underline{w}, \bar{b})_{o}$ & $(\underline{w}, \underline{b})_{o}$ \\
\cline { 1 - 1 }$\pi_{1}$ & & $(\bar{w}, \bar{b})_{y}$ & $q$ & $1-q$ & & \\
$\pi_{2}$ & & $(\bar{w}, \underline{b})_{y}$ & & 1 & & \\
$\pi_{3}$ & & $(\underline{w}, \bar{b})_{y}$ & $r q$ & $r(1-q)$ & $(1-r) q$ & $(1-r)(1-q)$ \\
$\pi_{4}$ & & $(\underline{w}, \underline{b})_{y}$ & & $r$ & & $1-r$ \\
\hline
\end{tabular}

Table 7: Markov matrix of type transition for women

Similar to the benchmark model, the uniqueness of the equilibrium is conditional on the distribution of agents' types in both periods. Overall, three equilibria exist. To characterize them, I first denote the expression $C=\pi_{1}(1-q)+\pi_{2}+\pi_{3} r(1-q)+$ $\pi_{4} r-\pi_{3}(1-p) q$. Together with the previously denoted expression $A=\pi_{1}(1-q)+$ $\pi_{2}+\pi_{3} p(1-q)+\pi_{4} p-\pi_{3}(1-p) q$, I can write the following conditions separating these three equilibia

$$
\begin{aligned}
& \left.\pi_{3}-\pi_{2}<C<A \quad \text { (Case } 3\right) ; \\
& \left.C<A<\pi_{3}-\pi_{2} \quad \text { (Case } 4\right) ;
\end{aligned}
$$

and

$$
C<\pi_{3}-\pi_{2}<A \quad(\text { Case } 5) .
$$


These three equilibria together with the respective measure of divorces for each case are formalized in Lemma 3.

Lemma 3: Given the distribution of agent characteristics and aging patterns supported by Case 3, Case 4, and Case 5 conditions, the equilibrium matching is unique and has the structure described by Table 8, Table 9, and Table 10 respectively.

Proof: In Appendix A 


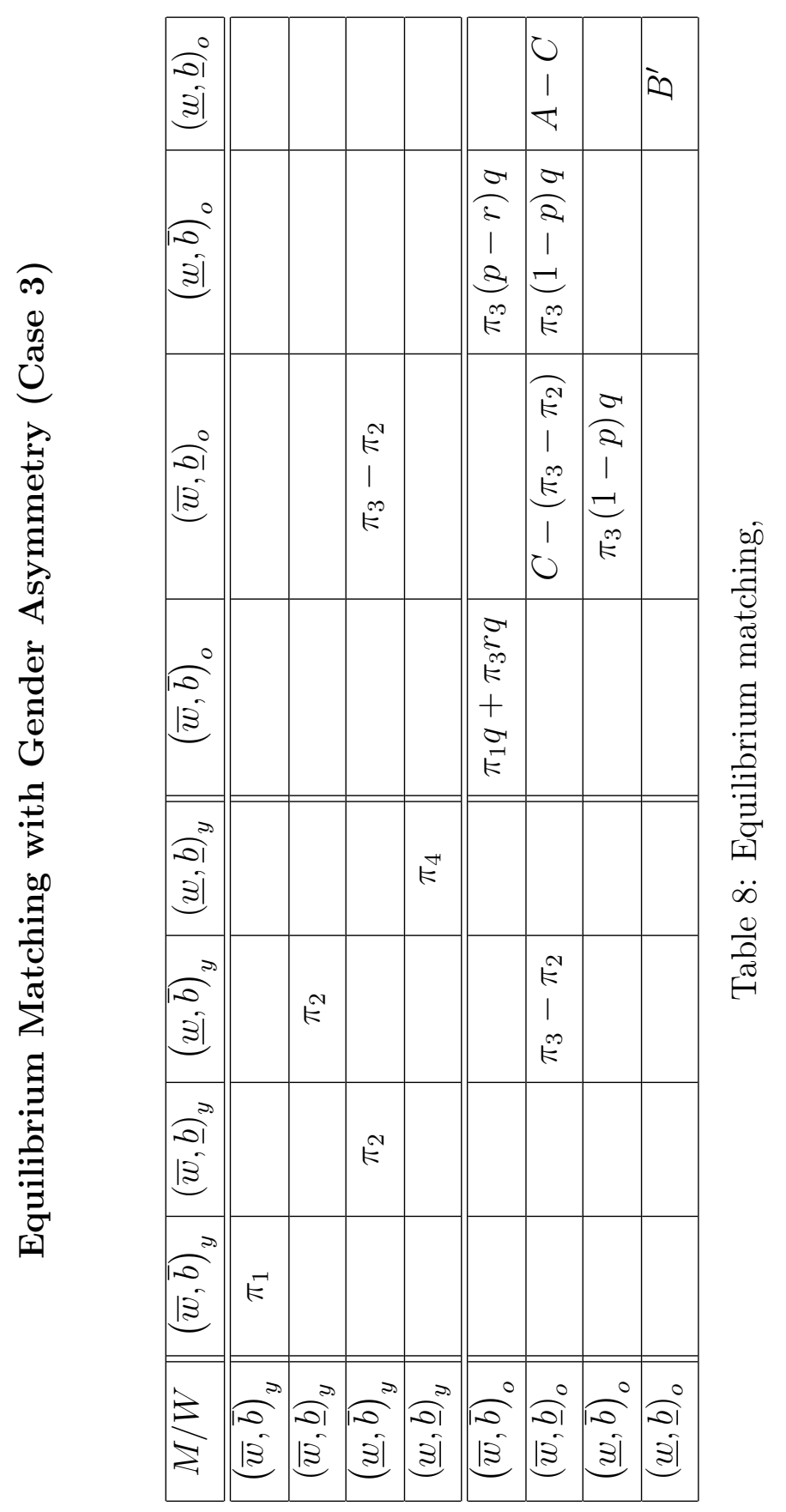

$\frac{1}{2}$

1
-1
2
+
$\frac{1}{2}$

I

$\underset{E}{\rightleftarrows} \stackrel{2}{\approx}$

ह

$+\underset{\Xi}{2}$

$\widetilde{0}$

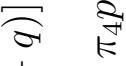

$\begin{array}{lll}0 & 1 & + \\ 1 & \frac{2}{2} & 1\end{array}$

$\underset{1}{7}$

$\stackrel{2}{=}$

i + i

I \&

$\frac{0}{\frac{0}{3}}$

है

है है

के

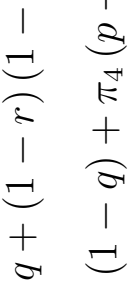

है ₹

है ।

के

$\stackrel{i}{=}$.

or

본

II

8

ธิ

$\frac{1}{8}$

\# 

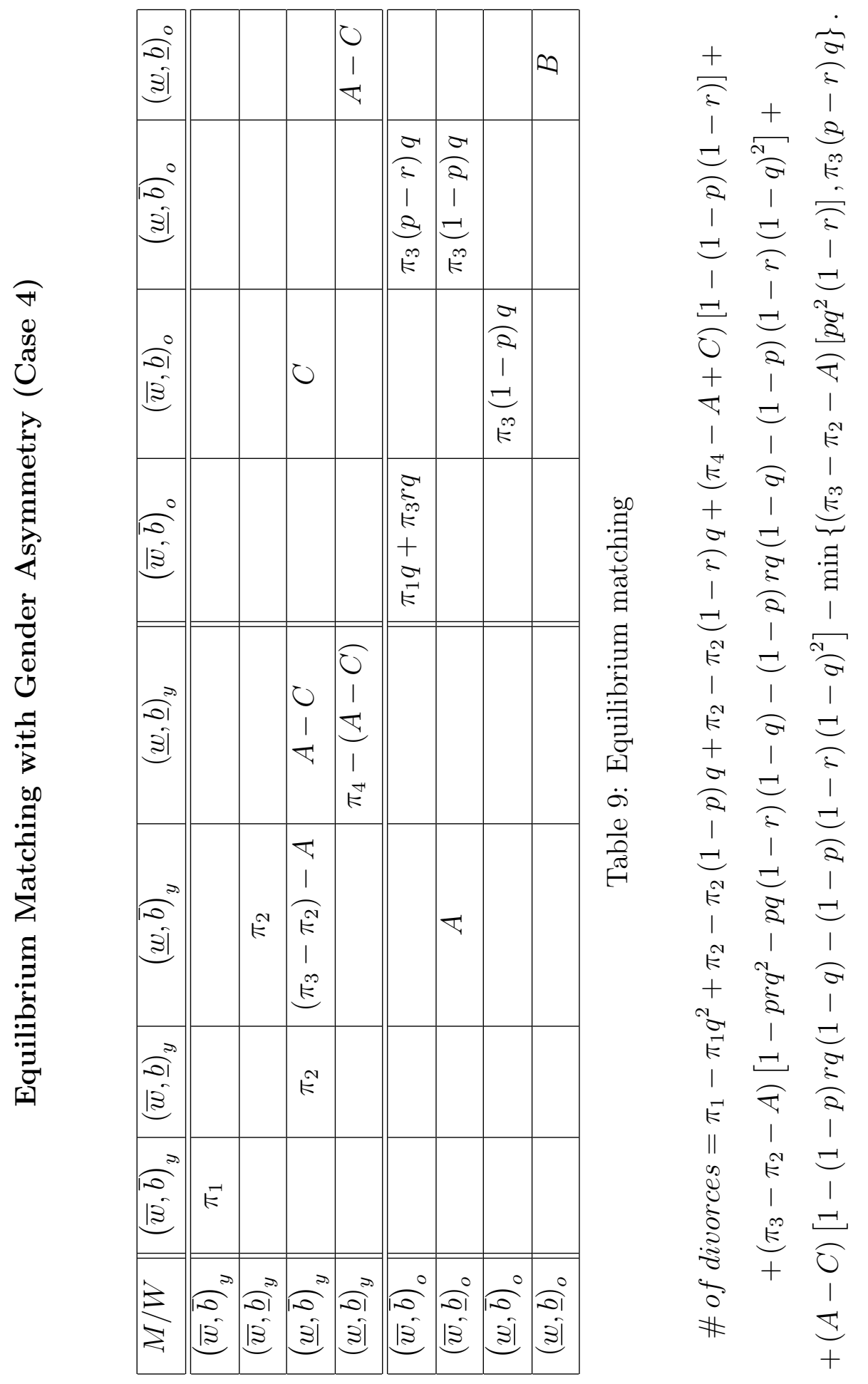

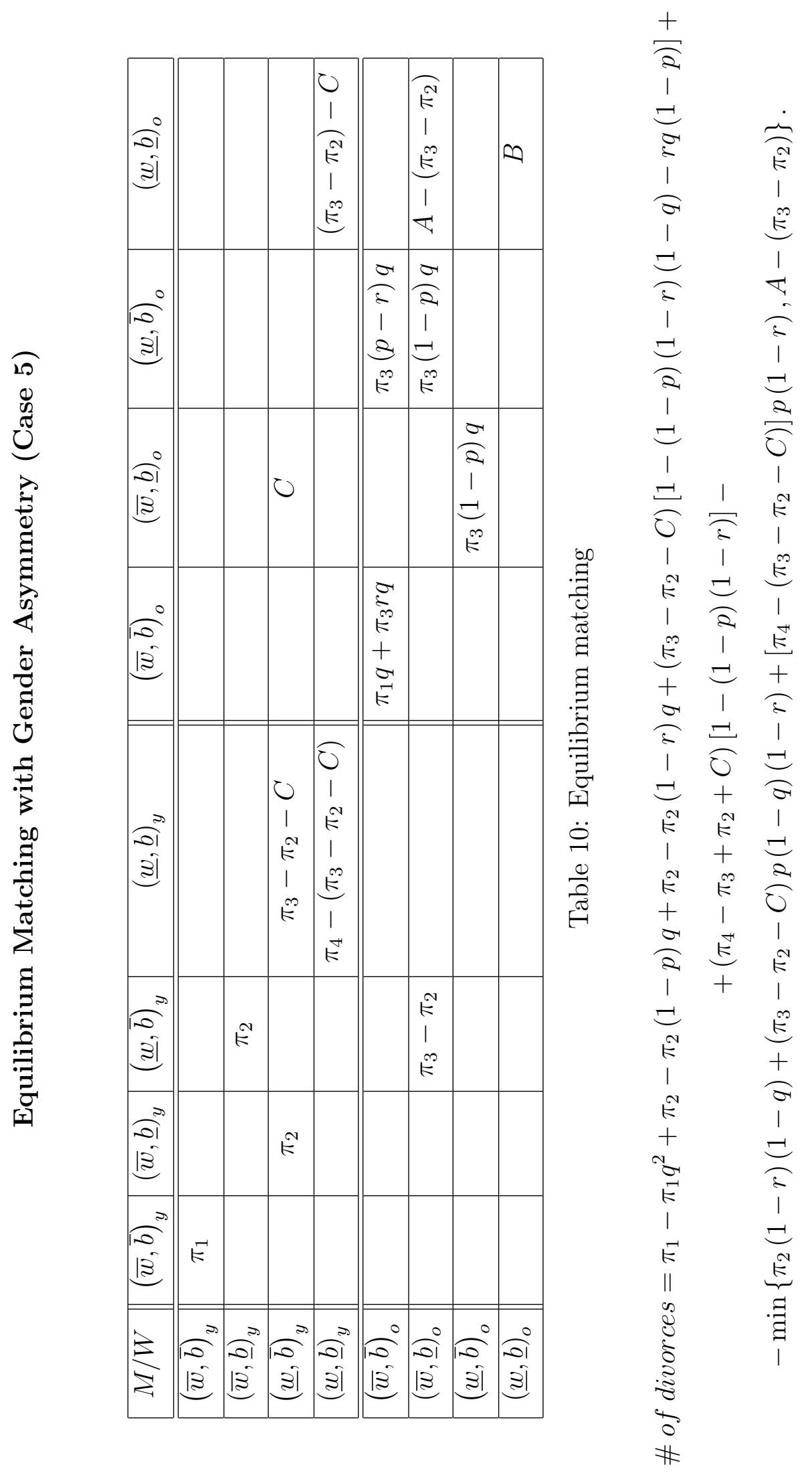
The aim of this section is to provide the reader with the comparative statics with respect to the gender asymmetry in future income prospects. To present a consistent analysis, Case 3 and Case 5 equilibria have to be compared with the benchmark Case 1 equilibrium since (3) as well as (5) imply $\pi_{3}-\pi_{2}<A$. On the other hand, Case 4 equilibrium has to be compared with the benchmark Case 2 equilibrium since (4) implies $A<\pi_{3}-\pi_{2}$. I concentrate especially on the changes in the divorce rate as a result of increasing female income prospects represented by the shift from the asymmetric case with female $\operatorname{Prob}\left(\bar{w}_{o} \mid \underline{w}_{y}\right)=r<p$ to the symmetric scenario with $\operatorname{Prob}\left(\bar{w}_{o} \mid \underline{w}_{y}\right)=p$ valid for both genders.

Since the overall number of marriages does not change over the time between the discussed equilibria, to analyze the change in the divorce rates as the effect of asymmetric aging, it is enough to compare the measures of divorces. To compute the measure of divorces, the same approach as in Case 1 was employed, and thus, it will not be described here in detail. However, it is important to note, that particularly in Case 3 as well as in the remaining equilibria, matches exist such as between $(\bar{w}, \underline{b})_{o}$ and $(\underline{w}, \underline{b})_{o}$ with the measure $A-C=(p-r)\left[\pi_{3}(1-q)+\pi_{4}\right]$, which goes to zero as $r \rightarrow p$. Therefore, the overall measure of match separations has to account for this fact since both matches between $(\bar{w}, \underline{b})_{y}$ and $(\underline{w}, \bar{b})_{y}$ and between $(\underline{w}, \underline{b})_{y}$ and $(\underline{w}, \underline{b})_{y}$ can potentially age into the match between $(\underline{w}, \bar{b})_{o}$ and $(\underline{w}, \underline{b})_{o}$, which may be of sufficient measure to accommodate all of these matches. The respective measures of divorces for Case 3, 4, and 5 equilibria are presented below Tables 8, 9, and 10 respectively and account for this fact by the inclusion of the minimum expression.

It is analytically straightforward to show that under condition (3) when Case 1 and Case 3 equilibria are compared, the measures of divorces are larger in Case 1. Moreover, this relationship is monotonic since the greater the value of $r$, characterizing female earning opportunities, the greater the measure of divorces is observed under condition (3). For the remaining two comparisons, precisely the comparisons between Case 2 and Case 4 equilibria and the comparison between Case 1 and Case 5 equilibria, I rely on simulation techniques over the whole range of feasible choices 
of $x, z, p, q$ and $r$. I found that these two remaining comparative statics are qualitatively the same as for the comparative statics between Case 1 and Case 3 equilibria. Therefore, I formalize this result without a proof ${ }^{2}$ in Proposition 2.

Proposition 2: The increase in the wife's income perspectives increases monotonically the overall measure of divorces. The divorce hazard increases for all types of matches with the exception of matches between the individuals of $(\bar{w}, \bar{b})_{y}$ type.

These findings, derived from the theoretical model I presented, are consistent with the empirical findings of Bremmer \& Kesselring (2004); Kalmijn \& Poortman (2006); Teachman (2010); and others, who found that the increase in the wife's earnings results in an increased divorce hazard. Moreover, the results indicate the monotonic relationship between female income perspectives and the measure of divorces since the greater the value of $r$, characterizing female earning opportunities, the greater the measure of divorces is observed. This suggests that the destabilizing effect of the increased opportunity to find a better partner is due to women becoming more desirable than the stabilizing effect of remaining desirable enough for the current partner.

\section{Conclusion}

The multidimensional model presented above introduces the concept of aging into the theoretical marriage market literature. I showed that changes in the agents' wealth and beauty over time as a representative of positive and negative aging effects can result in the incentive to re-match, and the probability of match separation is conditional on the agent's type. Therefore aging, modeled via the changes in the agents' characteristics, provides yet another explanation of the phenomenon of divorce and thus complements the existing theories explaining divorce mainly as a result of the on-the-job search or delayed realization of the match quality.

\footnotetext{
${ }^{2}$ The simulations to compare the measure of divorces for the respective equilibria were conducted for the space of parameters $x, z, p, q$, and $r$ with the step 0.01 .
} 
In addition, the presented concept provides a mechanism to account for the effects such as an increasing female labor force participation and the diminishing wage gap between males and females on the structure and, more importantly, on the stability of the marriage market, which has not been possible using up-to-date models with time invariant agents' characteristics. Several important real world observations can be described by the model. First, the equilibrium structure and the stability of the marriage market depend on the distribution of agents' types. Second, the increase in female income prospects increases the measure of divorces, which is in line with the empirical findings.

Even though the model presented in the paper is surely a simplistic generalization of the marriage market, it contributes to the existing literature by introducing aging as one of the explanations for the existence of divorce. This paper demonstrates the possibilities of the presented concept to evaluate the effects the continuing gender labor market equalization have on the marriage market. In addition, further research concentrating on the gender asymmetry in agents' wealth distribution can be a valid extension of the paper. 


\section{APPENDIX}

\section{Proof of Proposition 1:}

The proof relies on Eeckhout (2000), who showed that if men and women can be assigned ranks in such way that any man and any woman with the same rank prefer each other above any other partner with a lower rank, then stable matching is unique. The particular ordering that satisfies this condition is presented in the following table:

\begin{tabular}{c|cc} 
& Men & Women \\
\hline 1. & $(\bar{w}, \bar{b})$ & $(\bar{w}, \bar{b})$ \\
2. & $(\bar{w}, \underline{b})$ & $(\underline{w}, \bar{b})$ \\
3. & $(\underline{w}, \bar{b})$ & $(\bar{w}, \underline{b})$ \\
4. & $(\underline{w}, \underline{b})$ & $(\underline{w}, \underline{b})$ \\
\hline
\end{tabular}

Table 11: Rank ordering

\section{Proof of Lemma 1:}

The matching mechanism follows the deferred acceptance algorithm introduced by Gale 6 Shapley (1962). An agent's ordering of potential partners follows Formula 1 or Formula 2, conditional on the agent's level of wealth. As stated in Proposition 1, equilibrium matching is unique for the given distribution of agents' types, which implies that Men Best Equilibrium is equal to the Women Best Equilibrium. Therefore, the choice of group proposing the match in the Gale-Shapley algorithm does not play a role in the equilibrium outcome. The distribution of agents' types of age 2 is given in Table 1.

The step-by-step matching procedure following Gale-Shapley algorithm with men proposing, under the restrictions stated in Lemma 1, is outlined in Table 12. 


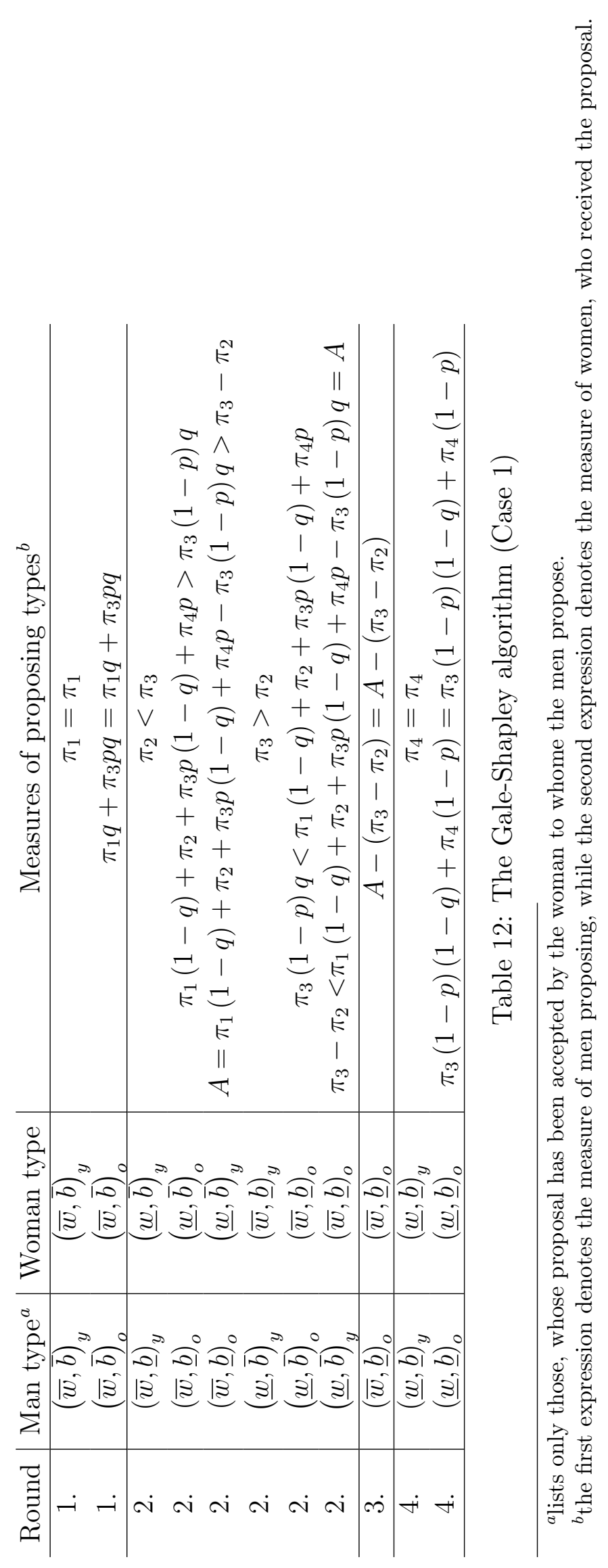




\section{Proof of Lemma 2:}

Again the matching mechanism follows the deferred acceptance algorithm introduced by Gale 85 Shapley (1962). An agent's ordering of potential partners follows Formula 1 or Formula 2, conditional on the agent's level of wealth. As in the previous case, the equilibrium is unique given the distribution of the agents' types, and therefore, the choice of group proposing the match in the Gale-Shapley algorithm does not play a role in the equilibrium outcome.

The step-by-step matching procedure following the Gale-Shapley algorithm with men proposing, under the restrictions stated in Lemma 2, is outlined in Table 13.

\section{Proof of Lemma 3:}

The matching mechanism follows the deferred acceptance algorithm introduced by Gale $E$ Shapley (1962). An agent's ordering of potential partners follows Formula 1 or Formula 2, conditional on the agent's level of wealth. As stated in Proposition 1, the equilibrium matching is unique for the given distribution of agents' types, which implies that the Men Best Equilibrium is equal to the Women Best Equilibrium. The distribution of agents' types of age 2 for men, is given by Table 1 and for women by Table 7. The step-by-step matching procedures following the Gale-Shapley algorithm with men proposing, under the restrictions stated in Lemma 3, are outlined in Tables 14, 15, and 16 for Case 3, 4, and 5 respectively. 


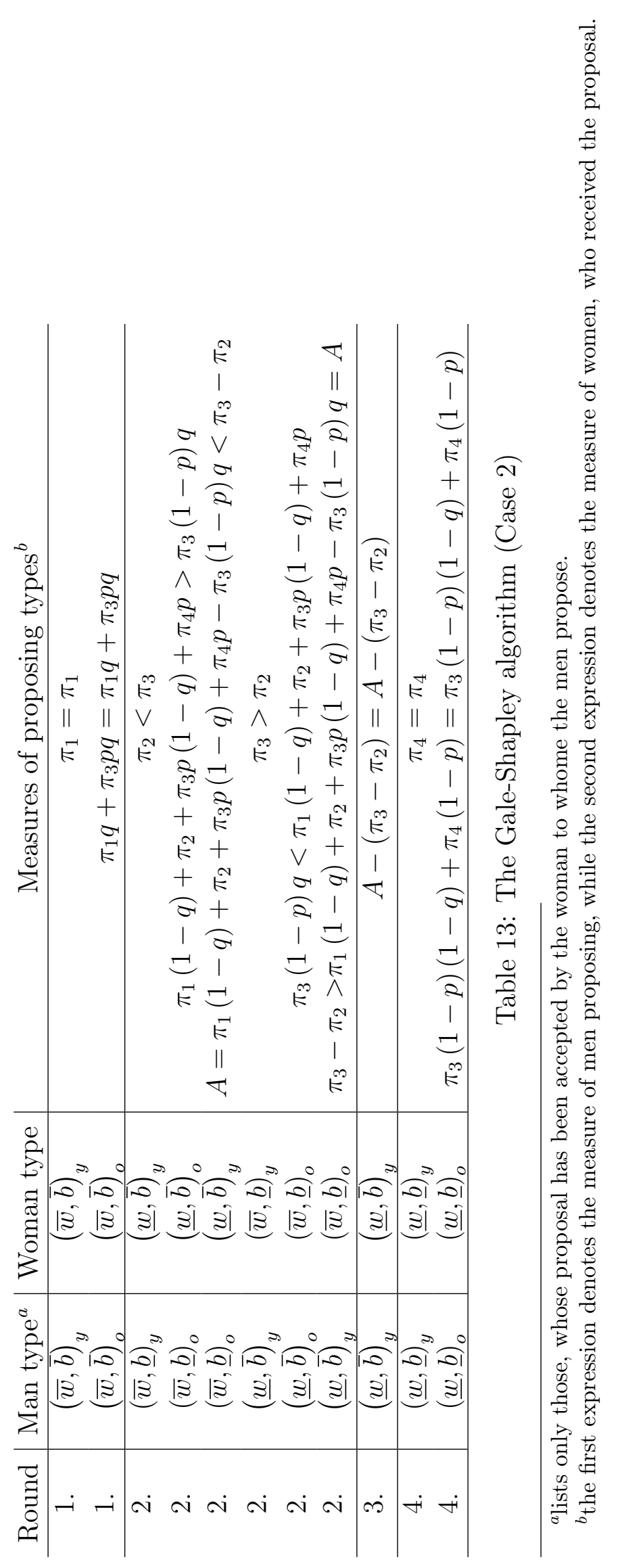




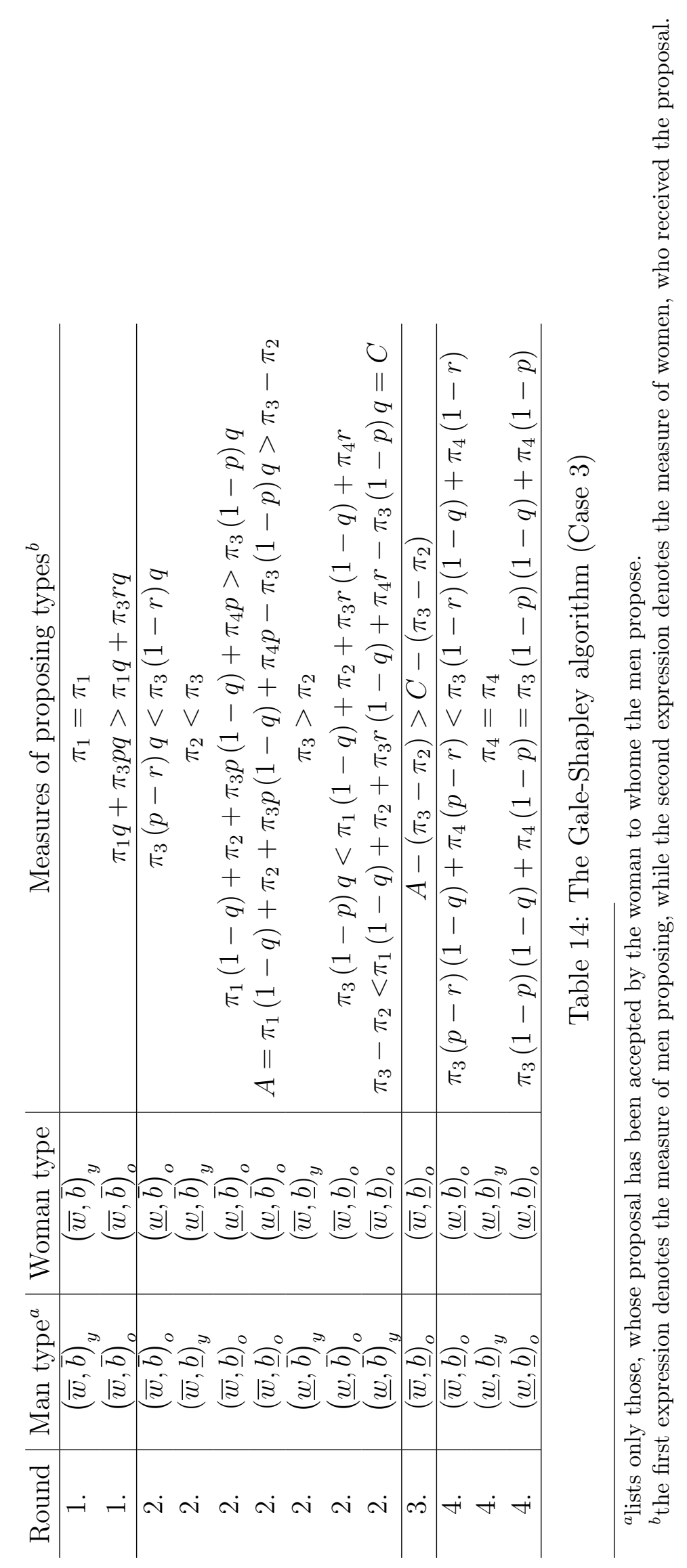




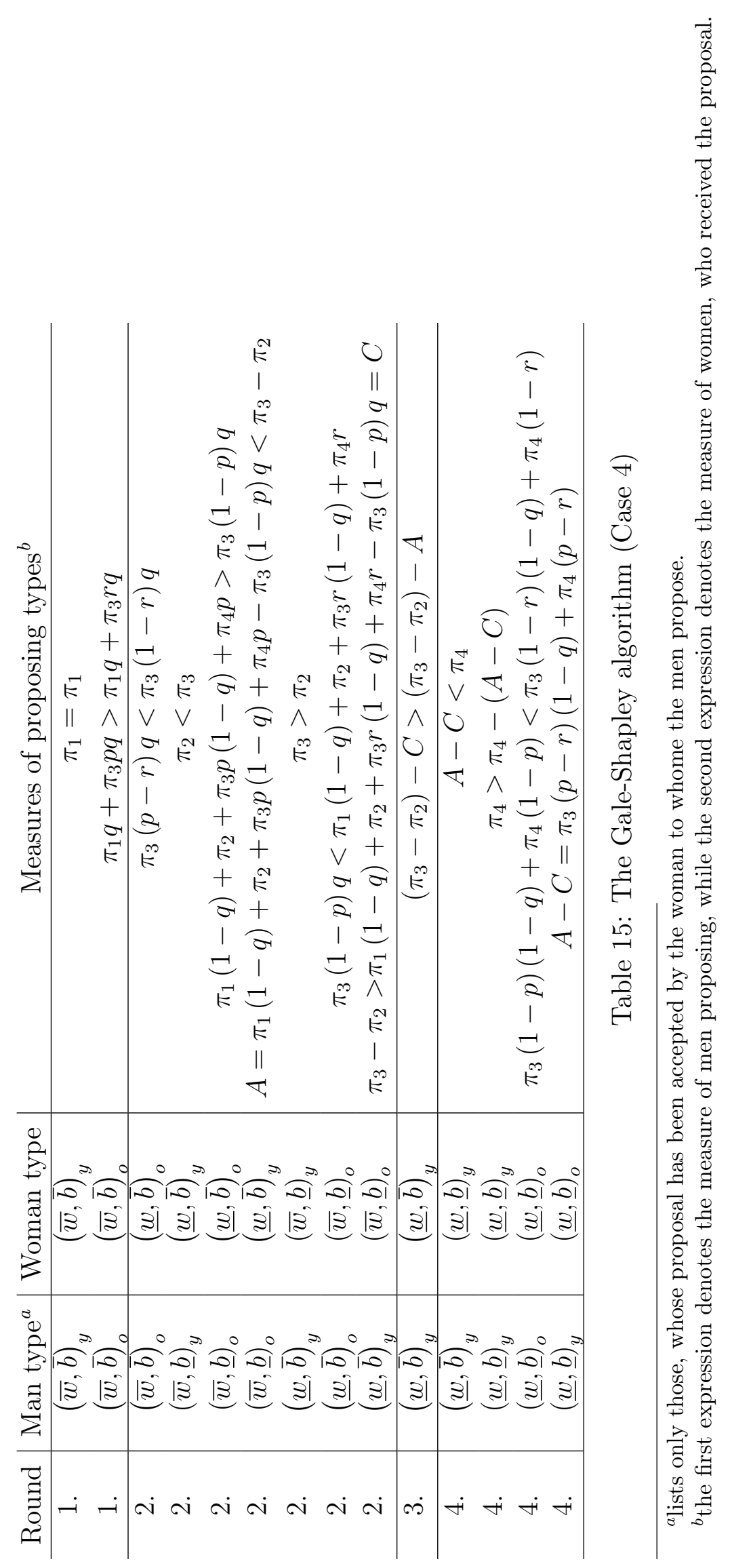




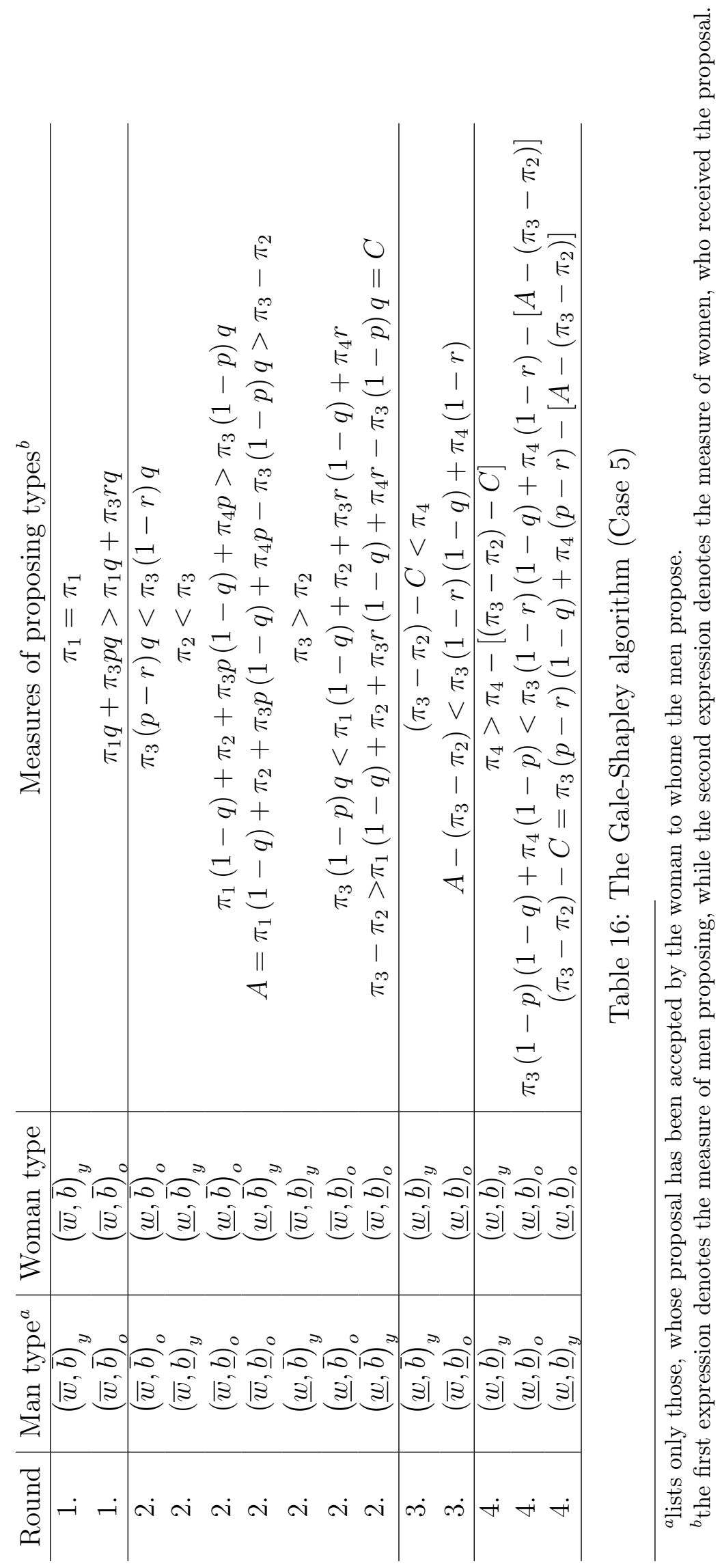




\section{References}

[1] Adachi, H. (2003). A search model of two-sided matching under nontransferable utility. Journal of Economic Theory, Vol. 113, No. 2, pp. 182-198.

[2] Becker, S. G. (1973). A theory of marriage I. Journal of Political Economy, Vol. 81, No. 4, pp. 813-846.

[3] Becker, S. G. (1974). A theory of marriage II. Journal of Political Economy, Vol. 82, No. 2, pp. S11-S26.

[4] Bergstrom, C.T. \& Bagnoli M. (1993). Courtship as a waiting game. Journal of Political Economy, Vol.1, No.1, pp. 185-202.

[5] Bjerk, D. (2009). Beauty vs earnings: Gender differences in earnings and priorities over spousal characteristics in matching model. The Journal of Economic Behavior \& Organization, Vol. 69, pp. 248-259.

[6] Bremmer, D. \& Kesselring, R. (2004). Divorce and female labor force participation: Evidence from times-series data and cointegration. Atlantic Economic Journal, Vol. 32, pp. 175-190.

[7] Burdett, K. \& Coles, G.M. (1997). Marriage and class. The Quarterly Journal of Economics, Vol. 112, pp. 141-168.

[8] Clark, S. (2006). The Uniqueness of Stable Matching. Contributions to Theoretical Economics, Vol. 6 : Iss. 1, Article 8.

[9] Cornelius, J. T. (2003). A search model of marriage and divorce. Review of Economic Dynamics, Vol. 6, No.1, pp. 135-155.

[10] Eeckhout, J. (2000). On the uniqueness of stable marriage matchings. Economics Letters, Vol. 69, No.1, pp. 1-8.

[11] Gale, D. \& Shapley, S.L. (1962). College admissions and the stability of marriage. The American Mathematical Monthly, Vol. 69, No.1, pp. 9-15.

[12] Hitsch, J. G., Hortasu, A. \& Ariely D. (2010). Matching and sorting in online dating. American Economic Review, Vol. 100, No.1, pp. 130-163.

[13] Kalmijn, M. \& Poortman, A.R. (2006). His or her divorce? The gendered nature of divorce and its determinants. European Sociological Review, Vol. 22, No.2, pp. 201-214.

[14] Mailath, G. J. \& Postlewaite, A. (2004). Social Assets, Second Version. (PIER Working Paper No. 04-025). Retrieved October 10, 2009, from http://ssrn.com/abstract $=555769$

[15] Masters, A. (2008). Marriage, commitment and divorce in a matching model with differential aging. Review of Economic Dynamics, Vol. 11, No. 3, pp. 614-628.

[16] Rasul, I. (2006). Marriage markets and divorce laws. The Journal of Law, Economics and Organization, Vol. 22, No. 1, pp. 30-69. 
[17] Shimer, R. \& Smith, L. (2000). Assortative matching and search. Econometrica, Vol. 68, No.2, pp. 343-369.

[18] Smith, L. (2006). The marriage model with search frictions. Journal of Political Economy, Vol. 114, No.6, pp. 1124-1144.

[19] Teachman, J. (2010). Wives' economic resources and risk of divorce. Journal of Family Issues, Vol. 20, No.10, pp. 1-19. 


\section{Working Paper Series}

ISSN 1211-3298

Registration No. (Ministry of Culture): E 19443

Individual researchers, as well as the on-line and printed versions of the CERGE-EI Working Papers (including their dissemination) were supported from the European Structural Fund (within the Operational Programme Prague Adaptability), the budget of the City of Prague, the Czech Republic's state budget and the following institutional grants:

- Center of Advanced Political Economy Research [Centrum pro pokročilá politickoekonomická studia], No. LC542, (2005-2010);

- Economic Aspects of EU and EMU Entry [Ekonomické aspekty vstupu do Evropské unie a Evropské měnové unie], No. AVOZ70850503, (2005-2010);

- Economic Impact of European Integration on the Czech Republic [Ekonomické dopady evropské integrace na ČR], No. MSM0021620846, (2005-2011);

Specific research support and/or other grants the researchers/publications benefited from are acknowledged at the beginning of the Paper.

(c) Mário Vozár, 2010

All rights reserved. No part of this publication may be reproduced, stored in a retrieval system or transmitted in any form or by any means, electronic, mechanical or photocopying, recording, or otherwise without the prior permission of the publisher.

Published by

Charles University in Prague, Center for Economic Research and Graduate Education (CERGE) and

Economics Institute ASCR, v. v. i. (EI)

CERGE-El, Politických vězňů 7, 11121 Prague 1, tel.: +420 224005 153, Czech Republic.

Printed by CERGE-EI, Prague

Subscription: CERGE-EI homepage: http://www.cerge-ei.cz

Phone: + 420224005153

Email: office@cerge-ei.cz

Web: http://www.cerge-ei.cz

Editor: Michal Kejak

Editorial board: Jan Kmenta, Randall Filer, Petr Zemčík

The paper is available online at http://www.cerge-ei.cz/publications/working_papers/.

ISBN 978-80-7343-215-7 (Univerzita Karlova. Centrum pro ekonomický výzkum a doktorské studium)

ISBN 978-80-7344-205-7 (Národohospodářský ústav AV ČR, v. v. i.) 
CERGE-EI

P.O.BOX 882

Politických vězňů 7

11121 Praha 1

Czech Republic http://www.cerge-ei.cz 